\title{
Aude Jeannerod, Le genre de la critique d'art chez J-K. Huysmans: fiction ou non fiction?
}

\section{Ida Merello}

\section{(2) OpenEdition}

1 Journals

\section{Edizione digitale}

URL: https://journals.openedition.org/studifrancesi/4780

DOI: $10.4000 /$ studifrancesi. 4780

ISSN: 2421-5856

\section{Editore}

Rosenberg \& Sellier

\section{Edizione cartacea}

Data di pubblicazione: 1 avril 2012

Paginazione: 176

ISSN: 0039-2944

\section{Notizia bibliografica digitale}

Ida Merello, «Aude Jeannerod, Le genre de la critique d'art chez J-K. Huysmans: fiction ou non fiction?», Studi Francesi [Online], 166 (I | LVI) | 2012, online dal 30 novembre 2015, consultato il 19 novembre 2021. URL: http://journals.openedition.org/studifrancesi/4780 ; DOI: https://doi.org/10.4000/ studifrancesi.4780

Questo documento è stato generato automaticamente il 19 novembre 2021.

\section{(c)}

Studi Francesi è distribuita con Licenza Creative Commons Attribuzione - Non commerciale - Non opere derivate 4.0 Internazionale. 


\title{
Aude Jeannerod, Le genre de la critique d'art chez J-K. Huysmans: fiction ou non fiction?
}

\author{
Ida Merello
}

\section{NOTIZIA}

AUDE JEANNEROD, Le genre de la critique d'art chez J-K. Huysmans: fiction ou non fiction?, «Revue d'histoire littéraire de la France», 2, 2011, pp. 341-356.

1 L'A. mette in evidenza come Huysmans tenda a indicare sempre l'occasione in cui si è trovato di fronte a un'opera, presentando ogni articolo come una sorta di narrazione che lo vede coinvolto come personaggio. Individua quindi la fitta interrelazione tra attività critica, diario di viaggio e scrittura romanzesca, per gli inserti di critica d'arte che entrano a far parte dei suoi romanzi, o sono parte integrante delle sue visite alle città. Se questa è una pratica piuttosto abituale negli scrittori critici d'arte, a cominciare da Gautier, l'A. rileva anche la caratteristica di Huysmans di immaginare suoni odori e movimento delle immagini dipinte. 